\title{
Earnings Management in State-Owned Enterprises in a Period of Macroeconomic Instability
}

\author{
Dimitris Balios, Apostolos Sdrolias \\ National and Kapodistrian University of Athens, Athens, Greece \\ Ioannis Thanos \\ Athens University of Economics and Business, Athens, Greece
}

\begin{abstract}
The purpose of this paper is to examine whether and to what extend Greek state-owned enterprises engage in earnings management techniques during 2012-2016. Most prior studies on earnings management have used data from large economies with relative stable macroeconomic contexts (e.g., USA). Our knowledge about earnings management in smaller economies is rather limited. To fill this void, we conducted our study in Greece and focused on the abovementioned period, which is very interesting given that Greece experienced a substantial political and macroeconomic instability (e.g., four elections, one referendum, capital controls, and two memorandums). Two different models (i.e., The Earnings Distribution Model and the Modified Jones Model) are used to provide answers to the research questions. The sample is composed of 50 state-owned enterprises. The results show that Greek state-owned enterprises did not adopt any earnings management techniques during the examined period. These results are rather robust given that they come from two different models. According to the literature, macroeconomic and political instability provide incentives to managers to use earnings management techniques. Interestingly though, our results suggest that this is not the case for a smaller economy. The findings of this study will allow investors, auditors, and users of the financial statements to make better decisions when studying companies that are experiencing those difficulties. The adoption of two different methods and the similar results is an indication of more robust and valid findings.
\end{abstract}

Keywords: earnings management, earnings quality, state-owned enterprises, macroeconomic instability

\section{Introduction}

Earnings management is a process that managers use their judgment in financial reporting and in structuring transactions to alter financial reports to either mislead stakeholders about the economic performance of the company or to influence contractual outcomes which depend on reported accounting numbers (Healy \& Wahlen, 1999). Earnings management has been a popular topic for research in the past two decades (e.g., Dechow \& Skinner, 2000; Cheng \& Warfield, 2005; Lo, 2008; Dechow, Hutton, Kim,\& Sloan, 2012; Fang, Huang, \& Karpoff, 2016; Gasteratos, Karamalis, Koutoupis, \& Filos, 2016; Amidu \& Issahaku, 2019; Beuselinck, Cascino, Deloof, \& Vanstraelen, 2019; Baker, Lopez, Reitenga, \& Ruch, 2019; Bzeouich, Lakhal,

Dimitris Balios, assistant professor, National and Kapodistrian University of Athens, Athens, Greece. 
\& Dammak, 2019; Lakhal \& Dedaj, 2019; Jerbi Maatougui \& Halioui, 2019; Makhaiel, 2019). A stream of research has specifically focused on earnings management in state-owned enterprises. Such enterprises are those that the state owns at least 30\% of their shares (Wang \& Yung, 2011). Prior studies have informed our understanding about several aspects of earnings management in state-owned enterprises. Still though, two factors hinder our further development of knowledge.

First, most prior earnings management studies have used data from large economies such as the USA, the UK, China, etc. (e.g., McNichols \& Wilson, 1988; Jones, 1991; Guenther, 1994; Kasanen, Kinnunen, \& Niskanen, 1996, Peasnell, 1998; C.J.P.Chen, S.Chen, \& Su, 2001). Earnings management is a global phenomenon though, and to better understand it we need to collect data from other economies too (e.g., Leuz, Nanda, \& Wysocki, 2003; Shen \& Chih, 2005; Chin, Chen, \& Hsieh, 2009; Kanagaretnam, Lim, \& Lobo, 2010; Degeorge, Ding, Jeanjean, \& Stolowy, 2013; Lemma, Negash, Mlilo, \& Lulseged, 2018). It is open to question, whether the results from advanced large economies can be generalised to less developed and smaller economies which have experienced periods of macroeconomic instabilities and crises (e.g., Chia, Lapsley,\& Lee, 2007; Habib, Uddin Bhuiyan,\& Islam,2013; Persakis \& Iatridis, 2016; Campa, 2019; Yung \& Root, 2019).

Second, as stressed in a recent literature review (Capalbo, Sorrentino, \& Smarra, 2018), the results of studies investigating earnings management in state-owned enterprises are contradictory. Some studies have argued in favour of a positive relationship between state ownership and earnings management (Guo \& Ma, 2015; Shleifer, 1998); some others have found a negative relationship (Aharony, Lee, \& Wong, 2000; Capalbo, Frino, Mollica, \& Palumbo, 2014); and some others no relationship (e.g., Wang \& Yung, 2011). These contradictory findings might be attributed to the different methods used by researchers to estimate earnings management in their studies, acknowledging the fact that this may arose for others factors as well. The fact that most studies employ only one method for measuring earnings management might not always depict an accurate image. Undeniably, every method has pros and cons and there is not a perfect one for measuring earnings management (Harris, Shi, \& Xie, 2018). Hence, the results of prior mono method studies might be driven by the method used and not be robust across different methods (Naidu \& Patel, 2013; Nan \& Park, 2017).

Considering the above two criticisms, we studied the potential use of earnings management techniques in Greek state-owned enterprises during the period 2012-2016. Our study makes two notable contributions to the earnings management literature.

First, unlike prior studies which come from large economies, we examined earnings management techniques in Greece. Greece represents an interesting setting for studying earnings management. It is an economy which has experienced a period of substantial macroeconomic instability in the past recent years. Greece during the examined time period experienced four elections, one referendum. Capital controls occurred for the first time in its history and two memorandums were also approved during that period. The term Grexit was coined to refer to the potential exit of Greece from the Eurozone. By studying Greece, we can infer as to whether earnings management techniques are used in other countries which have experienced or will experience in the future similar macroeconomic instabilities. In this way, our findings have broader implications for other economies too. The Greek construction sector is traditionally experiencing increase of earnings management in periods of higher capital tax rate, with large companies resorting to this practice more than the small ones (Gasteratos et al., 2016). Will this be translated to the state-owned enterprises as well?

Second, we focused on state-owned enterprises and in contrast to previous mono-method studies, we 
adopted two methods for estimating the use of earnings management techniques. The first method is the Earnings Distribution Model as proposed by Burgstahler and Dichev (1997). The second is the Modified Jones Model which was introduced in the literature by Dechow, Sloan, and Sweeney (1995). Using two methods gives us the possibility to estimate more robust and concrete results and shed light on the previous inconsistent findings of earnings management studies in state-owned enterprises.

The rest of the paper is organized as follows. Section two presents prior research on earnings management. Section three presents the two models that will be used for the analysis and advances the hypotheses. Section four includes the methodology used in this paper. Section five presents information about the data used and provides descriptive statistics about the sample. Section six reports the results of the study. Finally, section seven includes the conclusions and limitations of the study.

\section{Literature Review}

Several researchers have studied earnings management. A widely accepted definition of earnings management has been offered by Healy and Wahlen (1999). They define earnings management as the choices made by managers to change the quality of the financial statements. Those actions aim to either mislead the shareholders about the performance of the company or to influence specific items of the statements (e.g., asset valuations). Vander Bauwhede, Willekens, and Gaeremynck (2003) note that there is a clear distinction between earnings management and earnings manipulation. Ronen and Yaari (2008) argue along similar lines and classify earnings management in three categories: black, white, and grey. Black goes hand in hand with earnings management with cases of fraud and opaqueness. White assists the transparency of the financial statements. Grey refers to exploitation of earnings management close to the legal line. International Standard on Auditing 240 (IAASB, 2015) defines earnings management as the fraudulent financial statement, which includes deliberate errors in order to deceive the people who study those statements and to manipulate the company's earnings.

There are many motives for a manager to use earnings management. Vander Bauwhede et al. (2003) observe that managers use those practices to achieve the initial goal that was set. H. DeAngelo, L. DeAngelo, and Skinner (1996), Chen, Lin, Wang, and Wu (2010), and Burgstahler and Eames (2006) conclude that managers use these techniques both in earnings and in accruals so that they can meet the market's expectations. Graham, Harvey, and Rajgopal (2005) argue that managers use earnings management to achieve smooth earnings rather than bigger company value. Ascioglu, Hegde, Krishnan, and Mcdermott (2012) show that the use of such practices is influenced by the firms' liquidity. Sletten, Ertimur, Sunder, and Weber (2018) argue that a rise of capital at the initial public offering and the large-scale exit, by pre-initial public offering shareholders at lockup expiration which is calculated to approximately 180 days later, create incentives for firms to manage earnings. According to Miloud (2013), when the aim of earnings management is to increase the attractiveness of the offered shares, it needs to go undetected by market participants. However, as Armstrong, Foster, and Taylor (2015) conclude, interested parties are usually aware that many companies make use of such techniques. Those parties tend to be more cautious and are not easily deceived by the initial results. Also, Mollik, Mir, Bepari, and McIver (2013) find that those practices were aiming to make the firms' earnings appear lower than what they were in reality with the type of industry being a crucial factor in using earnings management.

Until recently, researchers did not pay attention to the impact of state ownership on earnings management 
(Wang \& Yung, 2011; Cinquini \& Tenucci, 2016). This is rather surprising given the profound and increasing impact that they have on several industries and national economies (OECD, 2014; Subramanian, 2016; Hope \& Vyas, 2017; Balios \& Zaroulea, 2020). H. Chen, J. Chen, Lobo, and Wang (2011) suggest that the incentives for monitoring earnings management are different between state-owned and non-state-owned firms. Many studies examine whether there is a relationship earnings management and state ownership (see Capalbo et al., 2018, for a thorough literature review). Results have been inconclusive to date.

Some studies argue that earnings management has a negative relationship with state ownership. Cheng, Wang, and Wei (2015) use a sample consisted of both state-owned and non-state-owned companies. Although they find evidence of earnings management in both categories, they conclude that the non-state-owned companies use earnings management in a far greater extent than the state-owned do. They state that those results are influenced by the access that state-owned companies have in more accessible and less costly funding. Moreover, they conclude that the fact that political decisions play a significant part in hiring a manager for the state-owned company contributes to the negative relationship with earnings management. Furthermore, Capalbo et al. (2014) state that the use of earnings management has a negative relationship with state ownership because the consequences of such actions would be more severe than in non-state-owned companies.

Other studies do not find a relationship between state ownership and earnings management. For example, Aharony et al. (2000) based on a sample of 83 Chinese state-owned companies during 1992-1995 conclude that there is no earnings management in these companies. Wang and Yung (2011), after analyzing a sample of 557 Chinese companies between the years 1998-2006, reach the same conclusion. Hoang, Abeysekera, and Ma (2014) based on a sample of 150 Vietnamese companies during 2005-2011 and Ding, H. Zhang, and J. Zhang (2007) based on a sample of 142 state-owned companies further argue that there is no relationship between earnings management and state ownership.

Finally, some studies support a positive relationship between earnings management and state ownership. Shleifer (1998) states that the positive relationship is achieved due to the low levels of governance that those entities have and the lower quality of controls. Guo and Ma (2015) after examining 1176 Chinese listed companies find that state ownership has a positive relationnship with earnings management, although firms are less likely to manipulate earnings when a state agency is the largest owner. Chen, Lee, and Li (2008) suggest that there is collusion between government and listed firms in earnings management. This earnings manipulation exists mainly in firms controlled by local governments. Finally, Ben-Nasr, Boubakri, and Cosset (2015) analyse 250 companies and find that when the state is the majority owner, earnings management is increased.

\section{Measurement of Earnings Management and Hypothesis Development}

Several models have been used in the literature to measure earnings management. Two of the most popular are the Earnings Distribution Model (Burgstahler \& Dichev, 1997) and the Modified Jones (1991) Model by Dechow et al. (1995). In the following paragraphs, we justify their selection and discuss their advantages and disadvantages. We selected these two models because they depict two different approaches, as far as interpreting a company's financial statement is concerned. The Earnings Distribution Model uses histograms and searches for discontinuities around the chosen threshold by taking into account the company's net income and its changes, whereas the Modified Jones Model examines the percentage of accruals that are considered to be unexplainable as a proxy of the level of earnings management, with the use of many variables. 
We combined those two methods in order to provide robust evidence about the magnitude of earnings management is the two methods which reach the same conclusion. If that was not the case, we will examine which are the reasons for the contradicting results. The analysis of the results was independent for each method in order to compare the results and conclude whether those were in correspondence with each other or in contradiction. Last but not least, the Modified Jones Model calculates the discretionary accruals as a proxy of the level of earnings management, whereas the Earnings Distribution Model does not estimate in any way the magnitude of earnings management. So, the main flaw of the latter method is estimated by the former one.

\section{Earnings Distribution Model}

The Earnings Distribution Model is an analysis based both in graphical and statistical data of the net income histogram. It speculates whether there are discontinuities around selected thresholds points. The writers support that those instances occur because the managers of those companies have definite motives in reporting higher profits and net income increases than reporting losses and net income decreases. The most common discontinuity is that of the zero-threshold mark. This study uses the same threshold mark as well. Furthermore, Degeorge, Patel, and Zeckhauser (1999) also studied the impact of earnings management at specific points of profitability with the use of this method. Last but not least, the same model was used by Coppens and Peek (2005) to examine the presence of earnings management in a sample that consisted of public and private European enterprises.

An advantage of this method is that it relies only on reported values and there is a complete absence of any estimation, as it is performed in the Modified Jones Model. Another advantage of this method lies in the simplicity to understand at certain thresholds how much earnings management affect the reported earnings. Finally, as Healy and Wahlen (1999) supported, the earnings distribution model investigates the effect of earnings management through cash flows. The Modified Jones Model, which uses the accruals, may not be able to find out this effect.

On the other hand, the major disadvantage of this method is that it can prove the existence of earnings management, but it cannot specify how earnings management is applied and at what is the magnitude of it. Morover, as Vander Bauwhede et al. (2003) specify, this method requires a large sample. Last but not least, Holland (2004) specifically points out that the method is sensitive to the chosen interval width.

We initially assume that there is earnings management in state owned enterprises. We follow Coppens and Peek (2005) and hypothesize the following:

Hypothesis 1: Earnings management is used to avoid reporting losses.

Hypothesis 2: Earnings management is used to avoid reporting earnings decreases.

\section{Modified Jones Model}

The Modified Jones Model measures the unexpected, discretionary, accruals. First, the total accruals are calculated. Then, the total accruals are regressed on variables to calculate the proxies of the expected, non-discretionary, accruals. Ideally, those proxies should be obtained from a period of time that there is no sign of earnings management and not calculated from our data. Finally, we calculated the unexpected accruals as the difference between the total accruals and the expected accruals. As Healy and Wahlen (1999) suggested, the unexpected accruals are the unexpected part of the total accruals.

One disadvantage of this method is that the unexpected accruals must be estimated. This may lead to biased results. Moreover, the Modified Jones Model measures the magnitude of earnings management through 
accruals. Earnings management can be achieved by other means as well, such as manipulation of the cash flows. Kothari, Leone, and Wasley (2005) criticise the variables used to measure the non-discretionary accruals and suggested performance matched discretionary accruals. Finally, this model cannot detect forms of earnings management which are less profound. (Dechow et al., 1995).

Ben-Nasr et al. (2015) find robust evidence that state ownership is associated with lower earnings quality. Starting from the evidence provided by Ben-Nasr et al. (2015) we examine whether managers in state-owned firms manipulate earnings or not. Thus, following their example the hypothesis for the Modified Jones Model is:

Hypothesis 3: State-owned enterprises are associated with earnings management techniques.

\section{Research Methodology}

Two different models were used to estimate earnings management: the Earnings Distribution Model and the Modified Jones Model. In the following paragraphs, we present the methodology of each model and then test our hypotheses.

\section{Earnings Distribution Model}

With the use of this model, we will investigate whether the distribution of the reported profits and their differences during this period years are concentrated around zero. Following Burgstahler and Dichev (1997), Beatty, Ke, and Petroni (2002), and Coppens and Peek (2005), we used the ROA (Return on Assets) and $\triangle$ ROA indicators. They were calculated as follows:

$$
\mathrm{ROA}_{\mathrm{t}}=\mathrm{KK}_{\mathrm{t}} / \mathrm{A}_{\mathrm{t}-1}
$$

Where:

- $\mathrm{ROA}_{\mathrm{t}}=$ Return on Assets in year $\mathrm{t}$,

- $\mathrm{KK}_{\mathrm{t}}=$ net income in year $\mathrm{t}$,

- $\mathrm{A}_{\mathrm{t}-1}=$ total assets in year $\mathrm{t}-1$.

Where:

$$
\Delta \mathrm{ROA}_{\mathrm{t}}=\Delta \mathrm{KK}_{\mathrm{t}} / \mathrm{A}_{\mathrm{t}-1}
$$

- $\Delta \mathrm{ROA}_{\mathrm{t}}=$ change in return on assets between year $\mathrm{t}$ and $\mathrm{t}-1$,

- $\mathrm{KK}_{\mathrm{t}}=$ change in net income between year $\mathrm{t}$ and $\mathrm{t}-1$,

- $\mathrm{A}_{\mathrm{t}-1}=$ total assets in year $\mathrm{t}-1$.

Then, we examined whether these distributions for discontinuities are around the zero threshold. Consistent with Coppens and Peek (2005), we used the t-statistic as follows:

$$
\mathrm{t}_{\mathrm{n}}=\left[\Delta \mathrm{P}_{\mathrm{n}}-\mathrm{MEAN}(\Delta \mathrm{Pi})\right] / \mathrm{STD}(\Delta \mathrm{Pi})
$$

Where:

- $\Delta \mathrm{Pn}=$ probability density of interval $\mathrm{n}$ minus the probability density of its neighbouring interval $\mathrm{n}-1$,

- $\operatorname{MEAN}(\Delta \mathrm{Pi})=$ mean of all differences between the probability densities of two neighbouring intervals within an area of 10 intervals surrounding interval $n$ and interval $n-1$,

- $\operatorname{STD}(\Delta \mathrm{Pi})=$ standard deviation of all differences between the probability densities of two neighbouring intervals within an area of 10 intervals surrounding interval $n$ and interval $n-1$.

If there were no discontinuities, then the standardized difference would be distributed approximately like the normal distribution with the mean value being 0 and a standard deviation of 1 . If the values are higher than 
the t-statistic critical value, then the hypotheses would be confirmed, and this would measure as a sign of earnings management. The t-statistic in both significance levels will be significantly different from 0 if our calculated values exceed the critical value of the t-statistic. We examined the same sample with different significance levels at $5 \%$ and $1 \%$.

\section{The Modified Jones Model}

In order to find out the magnitude of earnings management, we use the Modified Jones Model. We aim with the use of this model to separate the expected accruals from the unexpected ones. The former is called nondiscretionary accruals whereas the latter one's discretionary accruals. In order to measure the total accruals, the use of the change in revenue and receivables, as well as the level of property plant and equipment, is essential. The estimation process of the accruals is the following one, as Dechow et al. (1995) suggest:

Total accruals:

$$
\mathrm{TA}_{\mathrm{t}}=\left(\Delta \mathrm{CA}_{\mathrm{t}}-\Delta \mathrm{CL}_{\mathrm{t}}-\Delta \mathrm{Cash}_{\mathrm{t}}+\Delta \mathrm{STD}_{\mathrm{t}}-\mathrm{Dep}_{\mathrm{t}}\right) /\left(\mathrm{A}_{\mathrm{t}-1}\right)
$$

Where:

- $\mathrm{TA}_{\mathrm{t}}=$ total accruals in year $\mathrm{t}$ scaled by total assets at $\mathrm{t}-1$,

- $\Delta \mathrm{CA}_{\mathrm{t}}=$ change in current assets between year $\mathrm{t}$ and $\mathrm{t}-1$,

- $\Delta \mathrm{CL}_{\mathrm{t}}=$ change in current liabilities between year $\mathrm{t}$ and $\mathrm{t}-1$,

- $\Delta \mathrm{Cash}_{\mathrm{t}}=$ change in cash and cash equivalents between year $\mathrm{t}$ and $\mathrm{t}-1$,

- $\Delta \mathrm{STD}_{\mathrm{t}}=$ change in debt included in current liabilities between year $\mathrm{t}$ and $\mathrm{t}-1$,

- Dep $_{\mathrm{t}}=$ depreciation and amortisation expense in year $\mathrm{t}$,

- $\mathrm{A}_{\mathrm{t}-1}=$ total assets in year $\mathrm{t}-1$.

Nondiscretionary accruals:

$$
\mathrm{NDA}_{\mathrm{t}}=\alpha_{1}\left(1 / \mathrm{A}_{\mathrm{t}-1}\right)+\alpha_{2}\left(\Delta \mathrm{REV}_{\mathrm{t}}-\Delta \mathrm{REC}_{\mathrm{t}}\right)+\alpha_{3}\left(\mathrm{PPE}_{\mathrm{t}}\right)
$$

Where:

- $\mathrm{NDA}_{\mathrm{t}}=$ nondiscretionary accruals in year $\mathrm{t}$ scaled by total assets at $\mathrm{t}-1$,

- $\alpha_{1}, \alpha_{2}, \alpha_{3}=$ company-specific parameters,

- $\mathrm{A}_{\mathrm{t}-1}=$ total assets in year $\mathrm{t}-1$,

- $\triangle \mathrm{REV}_{\mathrm{t}}=$ change in net revenue between year $\mathrm{t}$ and $\mathrm{t}-1$ scaled by total assets at $\mathrm{t}-1$,

- $\triangle \mathrm{REC}_{\mathrm{t}}=$ change in net receivables between year $\mathrm{t}$ and year $\mathrm{t}-1$ scaled by total assets,

- at $\mathrm{t}-1$,

- $\mathrm{PPE}_{\mathrm{t}}=$ property plant and equipment in year $\mathrm{t}$ scaled by total assets at $\mathrm{t}-1$.

The company-specific parameters $\alpha_{1}, \alpha_{2}, \alpha_{3}$ were calculated using the following model.

$$
\mathrm{TA}_{\mathrm{t}}=\mathrm{a}_{1}\left(1 / \mathrm{A}_{\mathrm{t}-1}\right)+\mathrm{a}_{2}\left(\Delta \mathrm{REV}_{\mathrm{t}}\right)+\mathrm{a}_{3}\left(\mathrm{PPE}_{\mathrm{t}}\right)
$$

Where:

- $\mathrm{TA}_{\mathrm{t}}=$ total accruals in year $\mathrm{t}$ scaled by total assets at $\mathrm{t}-1$,

- $a_{1}, a_{2}, a_{3}=$ Ordinary Least Squares (OLS) estimates of $\alpha_{1}, \alpha_{2}, \alpha_{3}$,

- $\mathrm{A}_{\mathrm{t}-1}=$ total assets at $\mathrm{t}-1$,

- $\triangle \mathrm{REV}_{\mathrm{t}}=$ change in net revenue between year $\mathrm{t}$ and $\mathrm{t}-1$ scaled by total assets at $\mathrm{t}-1$,

- $\mathrm{PPE}_{\mathrm{t}}=$ property plant and equipment in year $\mathrm{t}$ scaled by total assets at $\mathrm{t}-1$.

At this point, it should be specified that we were unable to obtain a period during which there were no signs of systematic earnings management because most of the companies' websites did not have records of 
balance sheets before 2012. In order to acquire the company-specific parameters, the current sample was used, despite the fact than in the hypothesis we assume that we expect that earnings management is applied during this period.

Finally, we subtract the nondiscretionary accruals from the total accruals in order to calculate the discretionary accruals.

\section{Discretionary accruals:}

$$
\mathrm{DA}_{\mathrm{t}}=\mathrm{TA}_{\mathrm{t}}-\mathrm{NDA}_{\mathrm{t}}
$$

Where:

- $\mathrm{DA}_{\mathrm{t}}=$ discretionary accruals in year $\mathrm{t}$ scaled by total assets at $\mathrm{t}-1$,

- $\mathrm{TA}_{\mathrm{t}}=$ total accruals in year $\mathrm{t}$ scaled by total assets at $\mathrm{t}-1$,

- $\mathrm{NDA}_{\mathrm{t}}=$ nondiscretionary accruals in year $\mathrm{t}$ scaled total assets at $\mathrm{t}-1$.

The discretionary accruals serve as a proxy of the level of earnings management used by the company during the period 2012-2016.

Finally, we used the one-sample t-statistic at the significance levels of $5 \%$ and $1 \%$ so that we can determine whether those accruals were statistically different from zero. If they were, then this would serve as evidence of earnings management.

\section{Sample-Descriptive Statistics}

Our sample consists of companies in which the state owns at least $30 \%$ of the total shares (Wang \& Yung, 2011). Our sample was collected after accessing the Balance Sheet and Other Financial Statements of the Central Administration for the year 2016 published by the General Accounting Office of Greece. The initial sample size consisted of 96 companies (seven listed companies in the Athens Exchange, which follow IFRS, the remaining follow Greek Accounting Standards). Because enterprises operating in financial industries follow different standards when presenting their financial statements, they were excluded from the sample following other studies (Leuz et al., 2003; Lo, Ramos, \& Rogo, 2017). Also, companies which were under liquidation were excluded from the sample, because low-quality financial statements are associated with companies which are under liquidation or bankrupt (Sundgren, 2009). Finally, non-profit state-owned organizations were excluded from the sample because they do not actively pursue profit to redistribute it to the owners (Verbruggen \& Christiaens, 2012). Therefore, their earnings should be ideally close to the zero threshold.

The above choices resulted in a sample size of 50 state-owned enterprises examined over the period 2012-2016. The selected period is based on the data availability. We were unable to find sufficient data before that period. Thus, we accessed the websites of these companies and located the balance sheets between the years 2012 and 2016. Finally, the appropriate data was accumulated and used the Excel spreadsheet to test our hypotheses.

In our sample, the Greek state ownership ranged from $35 \%$ to $100 \%$. The mean value of state ownership was $91.79 \%$. There were only two instances, where the state-owned less than $50 \%$ of the company shares. Table 1 provides descriptive statistics for the minimum, maximum, median, and mean value as well as the standard deviation for the state ownership, the total assets, the net income, the current assets and liabilities, the depreciation and amortisation, and the net revenues of the companies that consist the sample. Our total number of observations was less than initially expected because a few companies established later than 2012 .

Table 1

Descriptive Statistics 


\begin{tabular}{|c|c|c|c|c|c|}
\hline & $\min$ & $\max$ & median & mean value & standard deviation \\
\hline State Ownership & $35 \%$ & $100 \%$ & $100 \%$ & $91.79 \%$ & 0.18 \\
\hline Total Assets & 446670.8 & 17373361000 & 65194286.87 & 1374206592.02 & 3319872984.14 \\
\hline Net Income & -617967000 & 678685803.24 & 72444.03 & -12757255.71 & 105755729.81 \\
\hline Current Assets & 132348.94 & 5013640000 & 23944540.82 & 294631063.88 & 707272323.6 \\
\hline Current Liabilities & 39989.74 & 8796792000 & 8351774.32 & 395730996.33 & 1238665861.34 \\
\hline Depreciation and Amortization & -789695.96 & 950845753.12 & 885447.22 & 48268952.16 & 149937454.9 \\
\hline Net Revenue & 140564.01 & 10468870000 & 9122364.75 & 427381059.86 & 1560745813 \\
\hline
\end{tabular}

\section{Findings}

\section{Earnings Distribution Model}

First, we follow Burgstahler and Dichev's (1997) model to present ROA and $\triangle \mathrm{ROA}$ in bar charts. The intervals we use in these charts are 0.005 and 0.01. As Holland (2004) mentions, the use of many intervals is crucial to ensure the significance of the results. Figure 1 and Figure 2 show net income and the changes in net income distribution with 0.005 interval width. Figure 3 and Figure 4 depict the net income and the changes in net income distribution with 0.01 interval width.

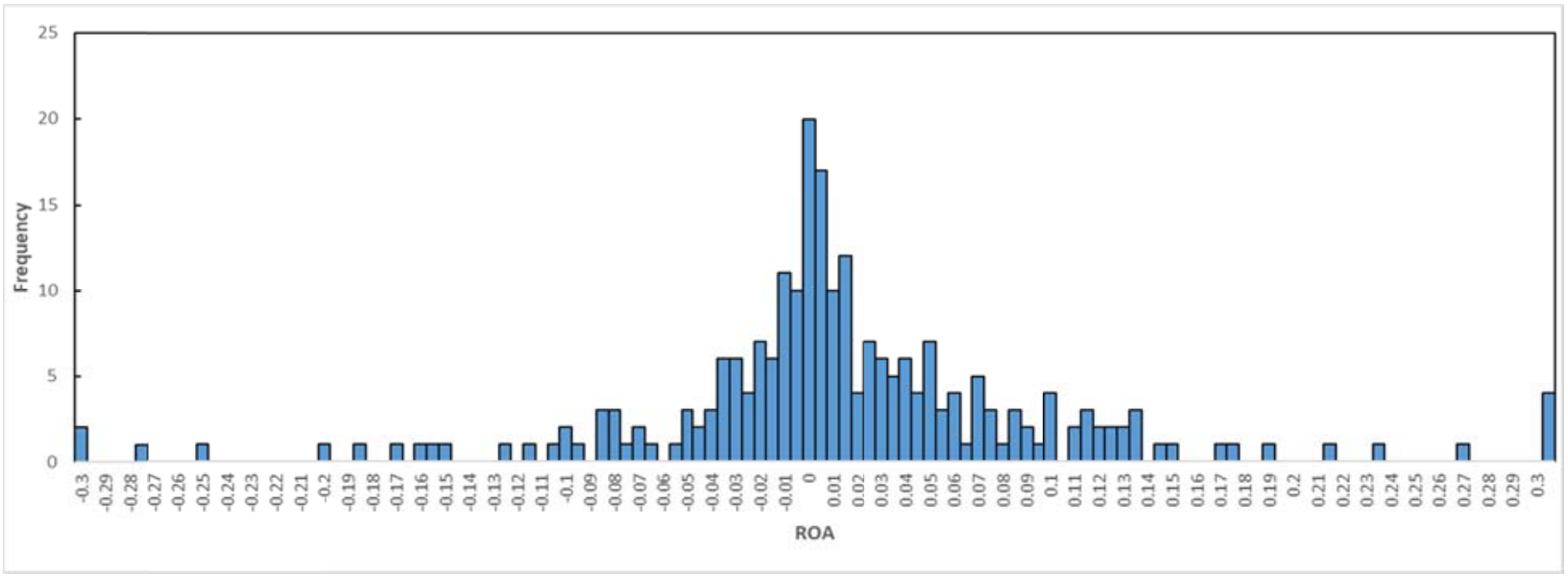

Figure 1. Net income distribution with 0.005 interval width.

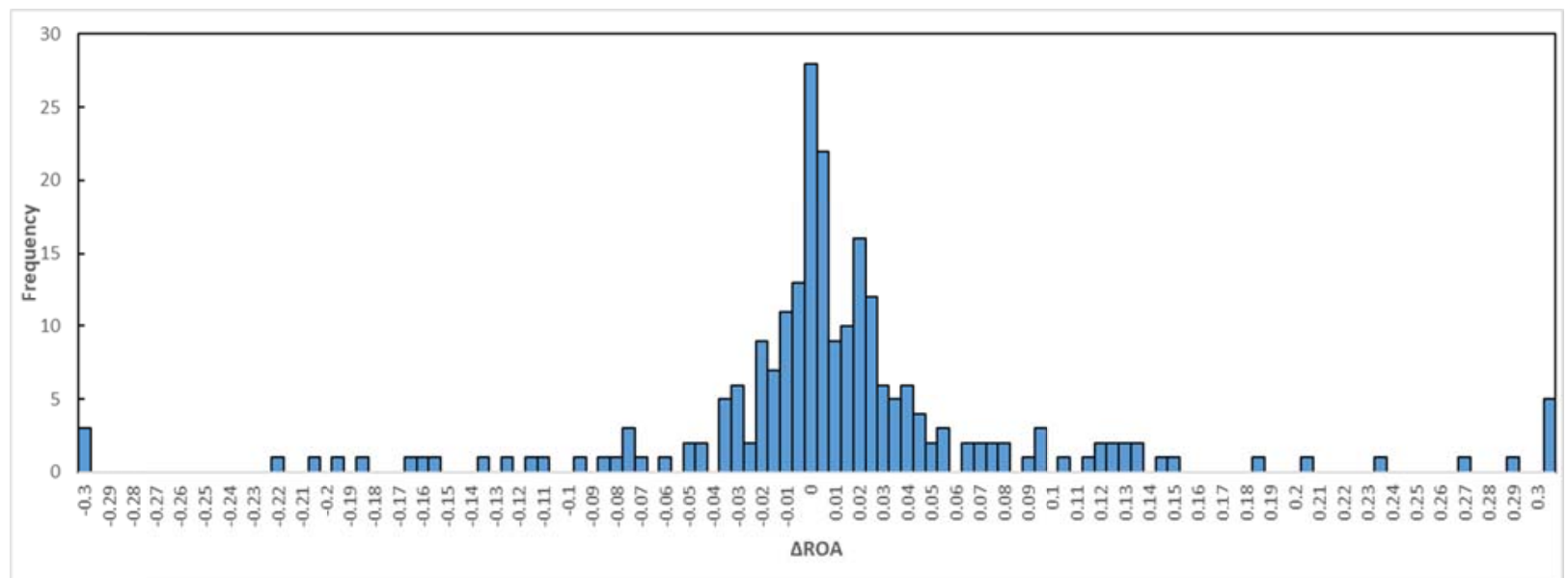

Figure 2. Changes in net income distribution with 0.005 interval width. 


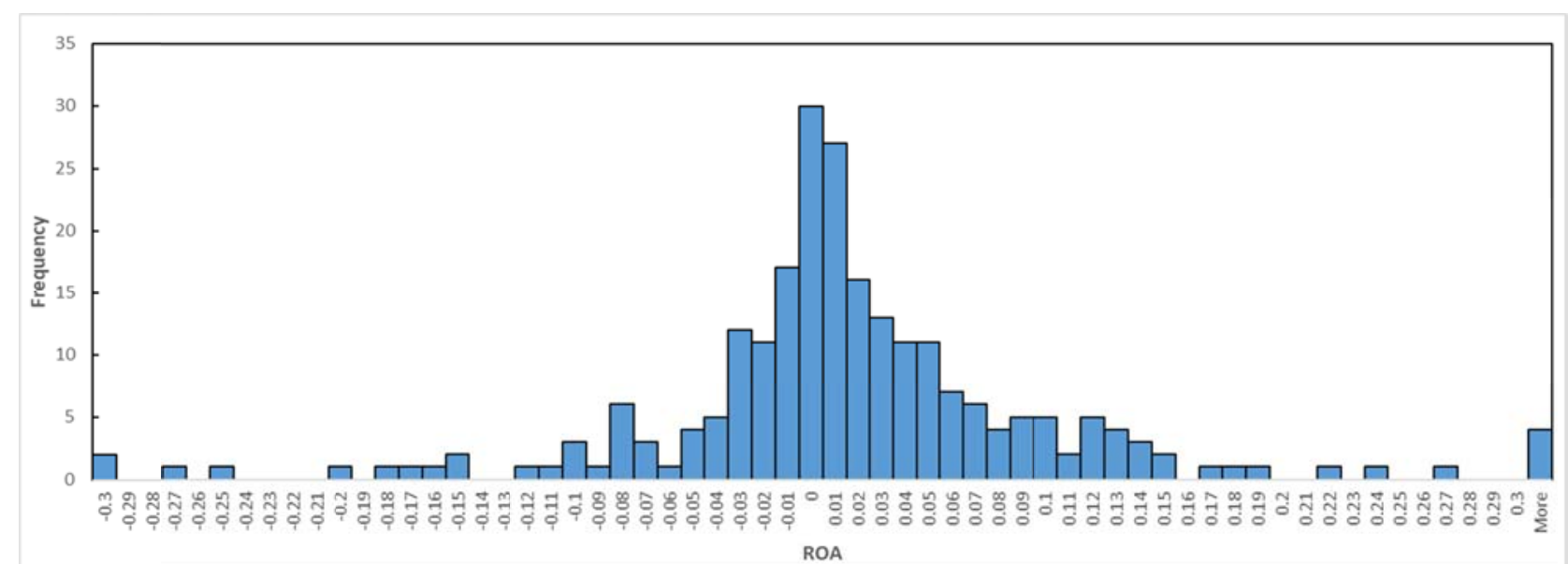

Figure 3. Net income distribution with 0.01 interval width.

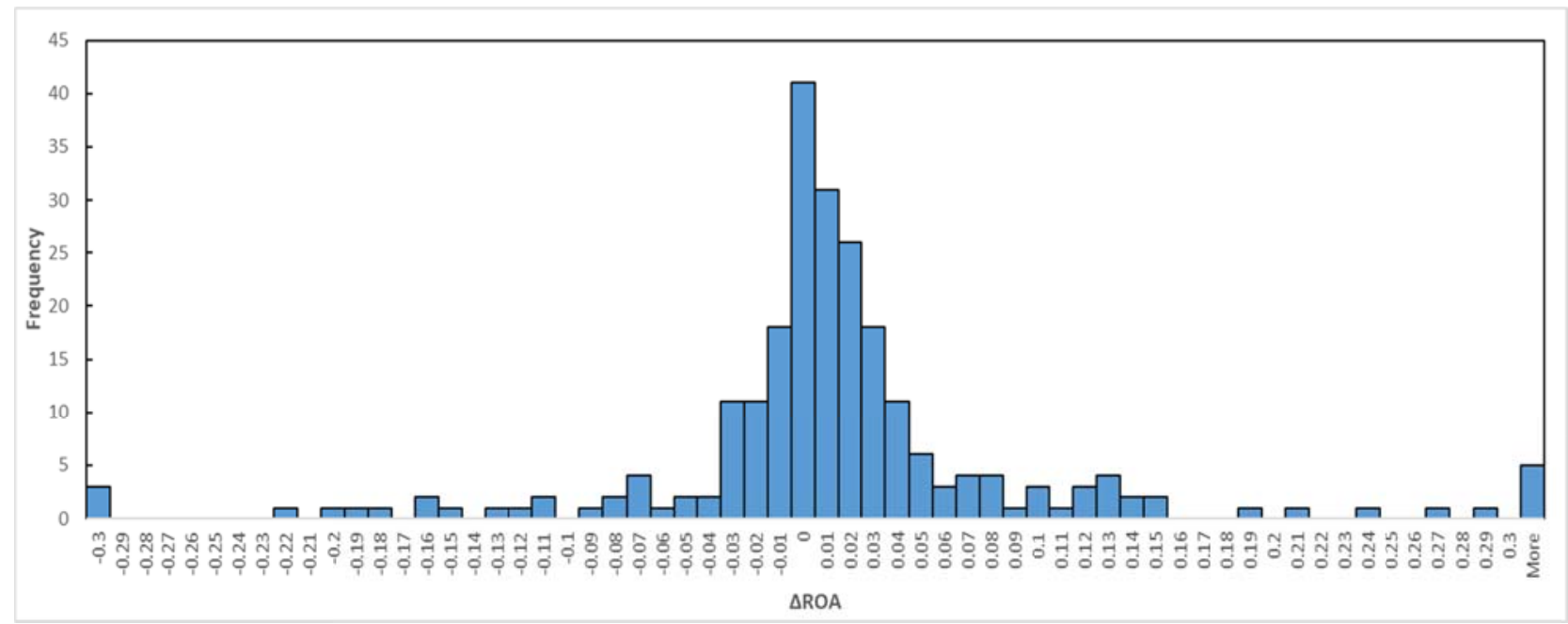

Figure 4. Changes in net income distribution with 0.01 interval width.

Then, following Coppens and Peek (2005), we used t-statistic for the intervals 0.005 and 0.01 . Table 2 depicts the results of the t-statistic for both intervals.

Table 2

T-Statistic with Interval Width of 0.005 and 0.01

\begin{tabular}{lll}
\hline Interval width & T-statistic & \\
\hline & ROA & $\Delta$ ROA \\
0.005 & 0.84 & 1.09 \\
0.010 & 0.64 & 1.55 \\
\hline
\end{tabular}

Then, we compared the numbers found with the respective critical values. These values are 2.093 and 2.861 , respectively, which are the critical values of the t-distribution with 19 degrees of freedom.

All the calculated values were lower than the critical values in both significance levels. Those findings suggest that state-owned enterprises in Greece did not show any sign of managing their earnings by avoiding to report loses or earnings decreases during the 2012-2016 period. Thus, Hypotheses 1 and 2 were not supported in both cases. More specifically: 
Table 3

Summary of the Results with the Use of Earnings Distribution Method With an Interval Width of 0.005 or 0.01 at a Significance Level of $5 \%$ and $1 \%$

\begin{tabular}{lll}
\hline Hypothesis & Result & Accept/reject \\
\hline $\begin{array}{l}\text { Earnings management is used in order to avoid } \\
\text { reporting losses. }\end{array}$ & No evidence of earnings management found & Reject \\
$\begin{array}{l}\text { Earnings management is used in order to avoid } \\
\text { reporting earnings decreases. }\end{array}$ & No evidence of earnings management found & \multirow{2}{*}{ Reject } \\
\hline
\end{tabular}

These results confirm previous findings by Aharony, Wang, and Yuan (2010), Capalbo et al. (2014), Cheng et al. (2015), Ding et al. (2007), Hoang et al. (2014), and Wang and Yung (2011). They all concluded that there was no evidence of earnings management in state-owned enterprises.

\section{The Modified Jones Model}

First, we calculated the total accruals based on the Modified Jones Model. Then, we used OLS to estimate the parameters for the calculation of the nondiscretionary accruals and come up with the discretionary accruals. Table 4 consists of the mean values and standard deviations of total, non-discretionary, and discretionary accruals. In addition, we present the aforementioned accruals as a percentage of the total accruals.

Table 4

Calculated Accruals with the Use of the Modified Jones Model

\begin{tabular}{|c|c|c|c|c|c|c|}
\hline \multirow{2}{*}{$\mathrm{N}=228$} & \multicolumn{2}{|c|}{ Total accruals } & \multicolumn{2}{c|}{ Nondiscretionary accruals } & \multicolumn{2}{c|}{ Discretionary accruals } \\
\cline { 2 - 7 } & Mean Value & Standard Deviation & Mean Value & Standard Deviation & Mean Value & Standard Deviation \\
\cline { 2 - 7 } & -0.0069 & 0.18 & -0.0065 & 0.56 & -0.0004 & 0.52 \\
\hline $\begin{array}{c}\text { Percentage (\%) of the total } \\
\text { accruals }\end{array}$ & \multicolumn{2}{|c|}{$100 \%$} & \multicolumn{2}{|c|}{$93.97 \%$} & & $6.03 \%$ \\
\hline
\end{tabular}

In Table 4 we see that the discretionary accruals are $6.03 \%$ of the total accruals. Because this percentage is small, we can conclude that the state-owned enterprises of the sample do not widely use earnings management strategies. Then we used a one-sample t-statistic test to examine if the percentage of the discretionary accruals is significantly different from 0 . The two tables below depict the results in significance levels $5 \%$ and $1 \%$ :

Table 5

One-Sample T-Statistic with a Significance Level of 5\%

\begin{tabular}{|l|c|}
\hline \multicolumn{2}{|c|}{$t$-Test: One Sample with significance level of 5\% } \\
\hline & DAt \\
\hline Mean & -0.0004 \\
\hline Variance & 0.2694 \\
\hline Observations & 228 \\
\hline$t$ Stat & -0.0121 \\
\hline $\mathrm{P}(\mathrm{T}<=\mathrm{t})$ one-tail & 0.4952 \\
\hline $\mathrm{t}$ Critical one-tail & 1.6516 \\
\hline $\mathrm{P}(\mathrm{T}<=\mathrm{t})$ two-tail & 0.9904 \\
\hline $\mathrm{t}$ Critical two-tail & 1.9705 \\
\hline
\end{tabular}

Both significance levels results concluded that the discretionary accruals were not significantly different from 0 . Thus, our hypothesis, which stated that there was evidence of earnings management, does not receive empirical support in any of the two significance levels. Hence, we argue that the state-owned companies in Greece were not using earnings management to manage their accruals during the 2012-2016 periods. 
Table 6

One-Sample T-Statistic with a Significance Level of 1\%

\begin{tabular}{|l|c|}
\hline \multicolumn{2}{|c|}{$\mathrm{t}$-Test: One Sample with significance level of $\mathbf{1} \%$} \\
\hline Mean & DAt \\
\hline Variance & -0.0004 \\
\hline Observations & 0.2694 \\
\hline $\mathrm{t}$ Stat & 228 \\
\hline $\mathrm{P}(\mathrm{T}<=\mathrm{t})$ one-tail & -0.0121 \\
\hline $\mathrm{t}$ Critical one-tail & 0.4952 \\
\hline $\mathrm{P}(\mathrm{T}<=\mathrm{t})$ two-tail & 2.3429 \\
\hline $\mathrm{t}$ Critical two-tail & 0.9904 \\
\hline
\end{tabular}

These results confirm previous findings by Aharony et al. (2010), Capalbo et al. (2014), Cheng et al. (2015), Ding et al. (2007), Hoang et al. (2014), and Wang and Yung (2011). They all concluded that there was no evidence of earnings management in state-owned enterprises.

\section{Discussion and Conclusion}

As stressed in the opening paragraphs of the paper, our knowledge about earnings management practices in state-owned enterprises has been shaped by studies conducted in large economies with relative stable macroeconomic conditions using one empirical method. Unlike prior empirical efforts, we attempted to contribute to the literature by studying earnings management practices in 50 state-owned enterprises in a small country (i.e., Greece) which experienced a period of substantial economic instability. The selected companies were of great importance because they operate in pivotal sectors of the economy, such as transport, telecommunications, energy, etc. Furthermore, these enterprises account for a large portion of the national GDP. We used two different empirical models (i.e., Earnings Distribution Model and the Modified Jones Model), which adds to the validity of our results.

To start with the Earnings Distribution Model, which examines the reported net income and their changes around the zero threshold, we did not find any discontinuities. Following Burgstahler and Dichev (1997) and Holland (2004), the selection of width intervals of 0.005 and 0.01 was used to test the hypotheses. After examination of a 10-interval width area around the zero threshold, there were not any discontinuities to be found. In all instances, the first two hypotheses did not receive empirical support.

Afterwards, the Modified Jones Model was used which has been proposed by Dechow et al. (1995). In contrast to the Earnings Distribution Model, which examines solely reported earnings, this model examines the accruals. In both cases, it turned out to be that the volume of the discretionary accruals was not significantly different from 0 . Thus, the third hypothesis was not confirmed.

After considering the results of both models, we reach the conclusion that there is no use of earning management practices in state-owned Greek enterprises during the period 2012-2016. This conclusion is robust given that the two models use different kind of variables and confirms the findings of the stream of research presented previously which suggested that there is no relationship between state-owned enterprises and earnings management (e.g., Aharony et al., 2010; Ding et al., 2007; Hoang et al., 2014; Wang \& Yung, 2011).

Our results have important implications for several parties including potential investors and auditors. In 
many occasions, the use of earnings management is associated with the manipulation of potential investors, who should be aware of the possibility that the companies use such methods. After all, if a company is involved in earnings management, the credibility of their financial statements will be in question. The same notion applies to the state-owned companies. Although, our results have a descriptive nature, they describe the tendencies of those companies. Those tendencies could be informative for many interesting parties in order to assess and estimate how similar enterprises may react under periods of economic instability. After all, the examined period was crucial for the Greek economy because of the macroeconomic instability. It was under scrutiny by different institutions, and two memorandums were passed by the Greek parliament. Being in an environment of constant surveillance could be the case why the Greek state-owned enterprises were publishing their financial statements without using any kind of earning management techniques. Thus, our study gives insight in earnings management literature of whether manipulation of earnings is used during periods of macroeconomic instability. In the same vein several researchers examined similar issues during financial crises and periods of macroeconomic unsteadiness. For instance, Chia et al. (2007) show those service-oriented companies engage in income decreasing earnings management during financial crisis. Habib et al. (2013) do not find evidence that financial destressed companies behave differently during global financial crisis. Persakis and Iatridis (2016) argue that lower audit quality implies lower earnings quality, irrespectively of the financial crisis. In addition, tax auditing mechanisms and forensic accounting are connected with tax evasion (Balios \& Tantos, 2019; Balios, Tantos, Eriotis, \& Vasiliou, 2020a; Balios et al., 2020b; Balios et al., 2020c) and earnings management. Further, Yung and Root (2019) indicate that policy uncertainty is positively associated with earnings management.

Our study has a few potential limitations. First, the sample size of 50 state-owned enterprises might be considered as relatively small. In addition, the examined period could be extended. Still though, we believe that the use of two different methods produces robust findings. Second, we assumed that earnings management was only to be found around the zero threshold. It is likely that earnings management may be performed in other thresholds or could be achieved with the assistance of other affiliated companies. Last but not least, the calculated parameters for the Modified Jones Model should ideally have come from a period that there were no signs of earnings management. Being unable to locate such a period, due to lack of information that was provided by the companies' websites, the calculation of those variables came from the available data of the 2012-2016 period. Finally, it would be interesting for future researchers to simultaneously investigate the same issue of whether big data can affect auditing and earnings management (see Balios, 2020; Balios et al., 2020 on big data and auditing) in several European countries.

\section{References}

Aharony, J., Lee, C. W. J., \& Wong, T. J. (2000). Financial packaging of IPO firms in China. Journal of Accounting Research, 38(1), 103-126. doi:10.2307/2672924

Aharony, J., Wang, J., \& Yuan, H. (2010). Tunnelling as an incentive for earnings management during the IPO process in China. Journal of Accounting and Public Policy, 29(1), 1-26. doi:10.1016/j.jaccpubpol.2009.10.003

Amidu, M., \& Issahaku, H. (2019). Do globalisation and adoption of IFRS by banks in Africa lead to less earnings management? Journal of Financial Reporting and Accounting, 17(2), 222-248. doi: 10.1108/JFRA-05-2017-0035

Armstrong, C. S., Foster, G., \& Taylor, D. (2015). Abnormal accruals in newly public companies: Opportunistic misreporting or economic activity? Management Science, 62(5), 1316-1338. doi:10.1287/mnsc.2015.2179

Ascioglu, A., Hegde, S., Krishnan, G., \& Mcdermott, J. (2012). Earnings management and market liquidity. Review of Quantitative Finance and Accounting, 38(2), 257-274. doi: 10.1007/s11156-010-0225-9 
Baker, T. A., Lopez, T. J., Reitenga, A. L., \& Ruch, G.W. (2019). The influence of CEO and CFO power on accruals and real earnings management. Review of Quantitative Finance and Accounting, 52(1), 325-345. doi: 10.1007/s11156-018-0711-z

Balios, D. (2020). The impact of big data on accounting and auditing. Forthcoming in International Journal of Corporate Finance and Accounting.

Balios, D., Tantos, S., Eriotis, N., \& Vasiliou, D. (2020a). The conjunction of tax auditing mechanism with behavioral and institutional parameters of tax evasion. The role of accounting rules and forensic accounting. European Journal of Accounting, Auditing and Finance Research, 8(2), 59-80.

Balios, D., Tantos, S., Eriotis, N., \& Vasiliou, D. (2020b). Effective corporate income tax rates: Southern and Northern economies of the European Union. International Journal of Accounting and Financial Reporting, 10(1), 117-144.

Balios, D. Tantos, S. Eriotis, N., \& Vasiliou, D. (2020c). Effective corporate income tax rates to the economies of the European Union in the light of the impact of the economic crisis in the Eurozone. International Journal of Economics and Business Administration, 6(1), 1-11.

Balios, D., Kotsilaras, P., Eriotis, N., \& Vasiliou, D. (2020). Big data, data analytics and external auditing. Journal of Modern Accounting and Auditing, 16(5), 211-219. doi: 10.17265/1548-6583/2020.05.002

Balios, D., \& Tantos, S. (2019). The characteristics of a fair and efficient tax auditing system as a tool against tax evasion: A theoretical framework. International Journal of Economics and Management Engineering, 13(6), 777-780.

Balios, D., \& Zaroulea, T. (2020). Corporate governance, internal audit and profitability: Evidence from P.I.G.S. countries. Journal of Accounting and Auditing: Research \& Practice, 2020, 1-17. doi: 10.5171/2020.668702

Beatty, A., Ke, B., \& Petroni, K. (2002). Earnings management to avoid earnings declines across publicly and privately held banks. The Accounting Review, 77(3), 547-570. doi: 10.2308/accr.2002.77.3.547

Ben-Nasr, H., Boubakri, N., \& Cosset, J. C. (2015). Earnings quality in privatized firms: The role of state and foreign owners. Journal of Accounting and Public Policy, 34(4), 392-416. doi: 10.1016/j.jaccpubpol.2014.12.003

Beuselinck, C., Cascino, S., Deloof, M., \& Vanstraelen, A. (2019). Earnings management within multinational corporations. The Accounting Review, 94(4), 45-76. doi: 10.2139/ssrn.1599678

Burgstahler, D., \& Dichev, I. (1997). Earnings management to avoid earnings decreases and losses. Journal of Accounting \& Economics, 24(1), 99-126. doi: 10.1016/S0165-4101(97)00017-7

Burgstahler, D., \& Eames, M. (2006). Management of earnings and analysts' forecasts to achieve zero and small positive earnings surprises. Journal of Business Finance and Accounting, 33(5-6), 633-652. doi: 10.1111/j.1468-5957.2006.00630.x

Bzeouich, B., Lakhal, F., \& Dammak, N. (2019). Earnings management and corporate investment efficiency: Does the board of directors matter? Journal of Financial Reporting and Accounting, 17(4), 650-670. doi: 10.1108/JFRA-06-2018-0044

Campa, D. (2019). Earnings management strategies during financial difficulties: A comparison between listed and unlisted French companies. Research in International Business and Finance, 50, 457-471. doi:10.1016/j.ribaf.2019.07.001

Capalbo, F., Frino, A., Mollica, V., \& Palumbo, R. (2014). Accrual-based earnings management in state owned companies: Implications for transnational accounting regulation. Accounting, Auditing \& Accountability Journal, 27(6), 1026-1040. doi: 10.1108/AAAJ-06-2014-1744

Capalbo, F., Sorrentino, M., \& Smarra, M. (2018). Earnings management and state ownership: A literature review. International Journal of Business and Management, 13(6), 117-128. doi: 10.5539/ijbm.v13n6p117

Chen, C. J. P., Chen, S., \& Su, X. (2001). Profitability regulation, earnings management, and modified audit opinions: Evidence from China. Auditing: A Journal of Practice \& Theory, 20(2), 9-30. doi: 10.2308/aud.2001.20.2.9

Chen, H., Chen, J., Lobo, G. J., \& Wang, Y. (2011). Effects of audit quality on earnings management and cost of equity capital: Evidence from China. Contemporary Accounting Research, 28(3), 892-925. doi: 10.1111/j.1911-3846.2011.01088.x

Chen, S., Lin, B., Wang, Y., \& Wu, L. (2010). The frequency and magnitude of earnings management: Timeseries and multi-threshold comparisons. International Review of Economics and Finance, 19(4), 671-685. doi: 10.1016/j.iref.2010.02.005

Chen, X., Lee, C. W. J., \& Li, J. (2008). Government assisted earnings management in China. Journal of Accounting and Public Policy, 27(3), 262-274. doi: 10.1016/j.jaccpubpol.2008.02.005

Cheng, C. A., Wang, J., \& Wei, S. X. (2015). State ownership and earnings management around initial public offerings: Evidence from China. Journal of International Accounting Research, 14(2), 89-116. doi: 10.1111/j.1467-8683.2007.00556.x

Cheng, Q., \& Warfield, T. D. (2005). Equity incentives and earnings management. The Accounting Review, 80(2), 441-476.doi: 10.2308/accr.2005.80.2.441

Chia, M. Y., Lapsley, I., \& Lee, H. (2007). Choice of auditors and earnings management during the Asian financial crisis. Managerial Auditing Journal, 22(2), 177-196.doi: 10.1108/02686900710718672 
Chin, C. L., Chen, Y. J., \& Hsieh, T. J. (2009). International diversification, ownership structure, legal origin and earnings management: Evidence from Taiwan. Journal of Accounting, Auditing \& Finance, 24(2), 233-262.doi: $10.1177 / 0148558 X 0902400205$

Cinquini, L., \& Tenucci, A. (2016). Strategic management accounting and business strategy: A loose coupling? Journal of Accounting \& Organizational Change, 6(2), 228-259.doi: 10.1108/18325911011048772

Coppens, L., \& Peek, E. (2005). An analysis of earnings management by European private firms. Journal of International Accounting, Auditing \& Taxation, 14(1), 1-17.doi: 10.1016/j.intaccaudtax.2005.01.002

DeAngelo, H., DeAngelo, L., \& Skinner, D. (1996). Reversal of fortune: Dividend policy and the disappearance of sustained earnings growth. Journal of Financial Economics, 40(3), 341-371. doi: 10.1016/0304-405X(95)00850-E

Dechow, P. M., \& Skinner, D. J. (2000). Earnings management: Reconciling the views of accounting academics, practitioners, and regulators. Accounting Horizons, 14(2), 235-250.doi: 10.2308/acch.2000.14.2.235

Dechow, P. M., Hutton, A. P., Kim, J. H., \& Sloan, R. G. (2012). Detecting earnings management: A new approach. Journal of Accounting Research, 50(2), 275-334.doi: 10.1111/j.1475-679X.2012.00449.x

Dechow, P. M., Sloan, R. G., \& Sweeney, A. P. (1995). Detecting earnings management. The Accounting Review, 70(2), $193-225$.

Degeorge, F., Patel, J., \& Zeckhauser, R. (1999). Earnings management to exceed thresholds. Journal of Business, 72(1), 1-33.doi: $10.1086 / 209601$

Degeorge, F., Ding, Y., Jeanjean, T., \& Stolowy, H. (2013). Analyst coverage, earnings management and financial development: An international study. Journal of Accounting and Public Policy, 32(1), 1-25.doi: 10.1016/j.jaccpubpol.2012

Ding, Y., Zhang, H., \& Zhang, J. (2007). Private vs. state ownership and earnings management: Evidence from Chinese listed companies. Corporate Governance: An International Review, 15(2), 223-238.doi: 10.1111/j.1467-8683.2007.00556.x

Fang, V. W., Huang, A. H., \& Karpoff, J. M. (2016). Short selling and earnings management: A controlled experiment. The Journal of Finance, 71(3), 1251-1294.doi: 10.1111/jofi.12369

Gasteratos, I., Karamalis, M., Koutoupis, A., \& Filos, I. (2016). Earnings management in Greece: A case study in construction sector using Jones model. International Journal of Economics and Business Administration, 4(4), 3-16.

Graham, J. R., Harvey, C. R., \& Rajgopal, S. (2005). The economic implications of corporate financial reporting. Journal of Accounting and Economics, 40(1-3), 3-73.doi: 10.1016/j.jacceco.2005.01.002

Guenther, D. A. (1994). Earnings management in response to corporate tax rate changes: Evidence from the 1986 Tax Reform Act. The Accounting Review, 69(1), 230-243.

Guo, F., \& Ma, S. (2015). Ownership characteristics and earnings management in China. The Chinese Economy: Translation and Studies, 48(5), 372-395.doi: 10.1080/10971475.2015.1067086

Habib, A., Uddin Bhuiyan, B., \& Islam, A. (2013). Financial distress, earnings management and market pricing of accruals during the global financial crisis. Managerial Finance, 39(2), 155-180.doi: 10.1108/03074351311294007

Harris, D. G., Shi, L., \& Xie, H. (2018). Does benchmark-beating detect earnings management? Evidence from accounting irregularities. Advances in Accounting, 41(C), 25-45.doi:10.1016/j.adiac.2018.04.001

Healy, P., \& Wahlen, J. M. (1999). A review of the earnings management literature and its implications for standard setting. Accounting Horizons, 13(4), 365-383.doi:10.2139/ssrn.156445

Hoang, T. C., Abeysekera, I., \& Ma, S. (2014). State ownership and earnings management: Empirical evidence from Vietnamese listed firms. In Proceedings of the 1st International Conference on Finance and Economics (pp. 257-268). Tomas Bata University, Zlín, Czech Republic.

Holland, D. (2004). Earnings management: A methodological review of the distribution of reported earnings approach. Social Science Research Network (SSRN).doi: 10.2139/ssrn.525242

Hope, O. K., \& Vyas, D. (2017). Private company finance and financial reporting. Accounting and Business Research, 47(5), 506-537.doi: 10.1080/00014788.2017.1303963

International Auditing and Assurance Standards Board (IAASB). (2015). Handbook of international quality control, auditing, review, other assurance and related services pronouncements. International Federation of Accountants (IFAC). ISBN: 978-1-60815-250-6

Jerbi, Maatougui, A., \& Halioui, K. (2019). The effect of outside blockholders on earnings management around seasoned equity offerings in French listed companies on the SBF120. Journal of Financial Reporting and Accounting, 17(3), 449-467.doi: 10.1108/JFRA-02-2018-0012

Jones, J. J. (1991). Earnings management during import relief investigations. Journal of Accounting Research, 29(2), 193-228.doi: $10.2307 / 2491047$ 
Jones, T. M. (1991). Ethical decision making by individuals in organizations: An issue-contingent model. Academy of Management Review, 16(2), 366-395.doi: 10.2307/258867

Kanagaretnam, K., Lim, C. Y., \& Lobo, G. J. (2010). Auditor reputation and earnings management: International evidence from the banking industry. Journal of Banking \& Finance, 34(10), 2318-2327.doi: 10.1016/j.jbankfin.2010.02.020

Kasanen, E., Kinnunen, J., \& Niskanen, J. (1996). Dividend-based earnings management: Empirical evidence from Finland. Journal of Accounting and Economics, 22(1-3), 283-312.doi: 10.1016/S0165-4101(96)00435-1

Kothari, S., Leone, A., \& Wasley, C. (2005). Performance matched discretionary accrual measures. Journal of Accounting and Economics, 39(1), 163-197.doi: 10.1016/j.jacceco.2004.11.002

Lakhal, N., \& Dedaj, B. (2019). R \& D disclosures and earnings management: The moderating effects of IFRS and the global financial crisis. Journal of Financial Reporting and Accounting, 18(1), 111-130.doi: 10.1108/JFRA-10-2019-0129

Lemma, T., Negash, M., Mlilo, M., \& Lulseged, A. (2018). Institutional ownership, product market competition, and earnings management: Some evidence from international data. Journal of Business Research, 90(C), 151-163.doi: 10.1016/j.jbusres.2018.04.035

Leuz, C., Nanda, D., \& Wysocki, P. (2003). Earnings management and investor protection: an international comparison. Journal of Financial Economics, 69(3), 505-527.doi: 10.1016/S0304-405X(03)00121-1

Lo, K. (2008). Earnings management and earnings quality. Journal of Accounting and Economics, 45(2-3), 350-357.doi: 10.1016/j.jacceco.2007.08.002

Lo, K., Ramos, F., \& Rogo, R. (2017). Earnings management and annual report readability. Journal of Accounting and Economics, 63(1), 1-25.doi: 10.1016/j.jacceco.2016.09.002

Makhaiel, N. (2019). The influence of Egyptian context on the trade-off between earnings management approaches: Accounting, operational and investment. Journal of Financial Reporting and Accounting, 17(1), 133-168. doi: 10.1108/JFRA-09-2017-0076

McNichols, M., \& Wilson, G. P. (1988). Evidence of earnings management from the provision for bad debts. Journal of Accounting Research, 26, 1-31.doi: 10.2307/2491176

Miloud, T. (2013). Earnings management and initial public offerings: An empirical analysis. Journal of Applied Business Research, 30(1), 117-134.doi: 10.19030/jabr.v30i1.8288

Mollik, A., Mir, M., Bepari, M. K., \& McIver, R. (2013). Earnings management during the global financial crisis: Evidence from Australia. In M. M. H. Bhuiyan (Ed.), Proceedings of International Business and Social Sciences Research Conference (pp. 1-27). World Business Institute Australia, Melbourne.

Naidu, D., \& Patel, A. (2013). A comparison of qualitative and quantitative methods of detecting earnings management: Evidence from two Fijian private and two Fijian state-owned entities. Australasian Accounting, Business and Finance Journal, 7(1), 79-98.doi: 10.14453/aabfj.v7i1.6

Nam, G., \& Park, J. W. (2017). A new approach to evaluating earnings management models. International Journal of Managerial and Financial Accounting, 8(3-4), 247-269.doi: 10.1504/IJMFA.2016.081855

OECD. (2014).The size and sectoral distribution of SOEs in OECD and partner countries. Paris: OECD Publishing.

Peasnell, K. V. (1998). Discussion of earnings management using asset sales: An international study of countries allowing noncurrent asset revaluation. Journal of Business Finance and Accounting, 25(9-10), 1319-1324.doi: 10.1111/1468-5957.00239

Persakis, A., \& Iatridis, G. E. (2016). Audit quality, investor protection and earnings management during the financial crisis of 2008: An international perspective. Journal of International Financial Markets, Institutions and Money, 41(C), 73-101.doi: 10.1016/j.intfin.2015.12.006

Ronen, J., \& Yaari, V. (2008). Definition of earnings management. InJ.S. Demski (Ed.), Earnings management emerging insights in theory, practice and research, Springer series in accounting scholarship 3 (pp. 25-38). Boston, MA: Springer.

Shen, C., \& Chih, H. (2005). Investor protection, prospect theory, and earnings management: An international comparison of the banking industry. Journal of Banking \& Finance, 29(10), 2675-2697.doi: 10.1016/j.jbankfin.2004.10.004

Shleifer, A. (1998). State versus private ownership. Journal of Economic Perspectives, 12(4), 133-150.doi: 10.1257/jep.12.4.133

Sletten, E., Ertimur, Y., Sunder, J., \& Weber, J. (2018). When and why do IPO firms manage earnings?Review of Accounting Studies, 23(3), 872-906.doi: 10.1007/s11142-018-9445-3

Subramanian, S. (2016). A comparison of corporate governance practices in state-owned enterprises and their private sector peers in India. IIM Kozhikode Society \& Management Review, 5(2), 200-216. doi: 10.1177\%2F2277975215617268

Sundgren, S. (2009). Perceived audit quality, modified audit opinions and the likelihood of liquidating bankruptcy among financially weak firms. International Journal of Auditing, 13(3), 203-221.doi: 10.1111/j.1099-1123.2009.00388.x 
Vander Bauwhede, H., Willekens, M., \& Gaeremynck, A. (2003). Audit firm size, public ownership and firms' discretionary accruals management. The International Journal of Accounting, 38(1), 1-22.doi: 10.1016/S0020-7063(03)00004-9

Verbruggen, S., \& Christiaens, J. (2012). Do non-profit organizations manage earnings toward zero profit and does governmental financing play a role? Canadian Journal of Administrative Sciences, 29(3), 205-217.doi: 10.1002/cjas.1219

Wang, L., \& Yung, K. (2011). Do state enterprises manage earnings more than privately owned firms? The case of China. Journal of Business Finance \& Accounting, 38(7-8), 794-812.doi: 10.1111/j.1468-5957.2011.02254.x

Yung, K., \& Root, A. (2019). Policy uncertainty and earnings management: International evidence. Journal of Business Research, 100(C), 255-267.doi: 10.1016/j.jbusres.2019.03.058 